\title{
Distribution of Intangible Assets in the Regions of the Russian Federation and Worldwide
}

\author{
Fakhrutdinova E.V. ${ }^{1}$, Kolesnikova J.S. ${ }^{2 *}$, Yagudin R.Kh. ${ }^{3}$ \\ ${ }^{1}$ Kazan (Volga Region) Federal University, 420008, Kazan,Kremlevskaya str, 18, efahr@mail.ru; \\ ${ }^{2}$ Institute of Socio-Political Research - Branch of the Federal Center of Theoretical and Applied Sociology of the \\ Russian Academy of Sciences (ISPR FCTAS RAS), 119333, Moscow, Fotieva str6 (1), hulia_k@mail.ru \\ ${ }^{3}$ Kazan (Volga Region) Federal University, 420008, Kazan,Kremlevskaya str, 18, rh65@mail.ru; \\ *Corresponding author. Email: hulia_k@mail.ru
}

\begin{abstract}
Digitalization of the economy leads to an increase in the role of intangible resources. Intellectual property, social and reputation capital are becoming drivers of territorial development. The paper considers the concentration of intangible assets in the regions of the Russian Federation, it is revealed that more than $90 \%$ of intangible assets in the country are concentrated in the Central Federal District. In a crisis, there is an increase in the concentration and share of intangible assets, because firms aim to increase assets. Intangible property acts as a tool for the capitalization of company assets. We have analysed the balances of companies that are in the top of the best global brands according to the Best Global Brand version. We analysed the share of intangible assets, the share of reputation and the total share of the intangible component (intangible assets and reputation in the total volume of assets). Companies leading the concentration of the intangible component are manufacturers of consumer goods, companies engaged in information technology and consulting services. Among foreign companies, manufacturers of luxury goods have a high level of immateriality. This trend is characteristic of foreign companies, however, in terms of total assets, they are not at the forefront, due to trade policy and the nature of their activities. The basis of the intangible property of these companies is the brand. In the context of digitalization, the brand value of the company will increase. It was highlighted that a characteristic feature for the Russian rating of intangible companies is the presence in it of representatives from the banking sector (Sberbank and Bank of Moscow) and the petrochemical complex (Lukoil) and companies involved in transportation (Russian Railways).
\end{abstract}

Keywords: intangible property, social capital, intangible assets, brand, concentration, capitalization

\section{INTRODUCTION}

In the context of digitalization, the role of intangible property is growing. Intangible goods (reputation, brand, intellectual resources, social capital) provide competitive advantages. At the macro level, the only indicator quantitatively reflecting the volume of intangible property is the volume of intangible assets. However, many intangible assets will not be reflected in intangible assets due to the nature of accounting standards. The volume of intangible assets in the period from 2003 to 2011 have a tendency to increase. Since 2012, the standards for compiling statistics have changed, small enterprises do not report on intangible assets, which does not allow analysing the volumes of intangible assets for a full range of organizations and, therefore, does not leave a general indicator of intangible property across the country. Since
2009 , there has been a significant increase in the indicator for intangible assets, this trend, we believe, can be associated with the behaviour of firms in a crisis (Fig. 1).

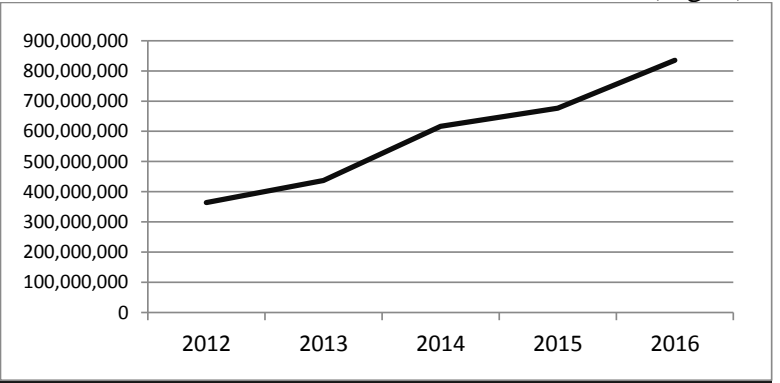

Figure 1 Dynamics of intangible assets in the Russian Federation. [1] 


\section{BACKGROUND}

The study will be based on the approaches that determined its purpose and objectives. The balance approach to the study will be applied in the assessment of intangible capital, partly through the statistical indicators of intangible assets in the construction of economic and statistical models. The resource approach to intangible capital has a manifestation in the study when determining the impact of intangible capital on the socio-economic development of the region, as a resource that provides additional competitive advantages.

The study applied general logical methods: analysis, synthesis, deduction and analogy. Comparison, observation and statistical analysis of data are also applied. The study is systemic.

In connection with a decrease in the market value of companies, it becomes necessary to capitalize intangible property; therefore, previously unaccounted assets are included in the balance sheet structure.

Deviation of the graph of the logarithm of the indicators from the trend in 2007-2008 also confirms the hypothesis that the indicators experienced an uncharacteristic effect in 2007-2008. (fig. 2)
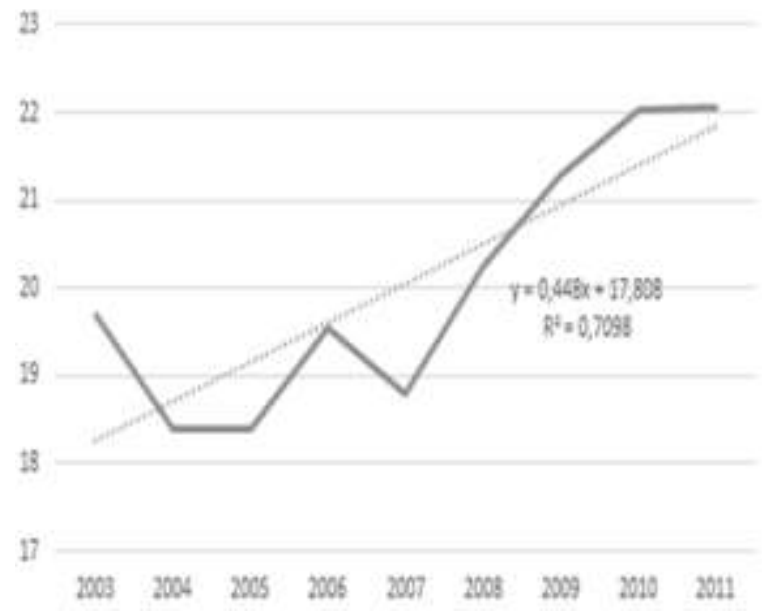

Figure 2 The logarithm of intangible assets [2]

A similar trend was observed in the world. The growth rate of intangible assets in 2007 (the onset of the crisis) was maximum (3).

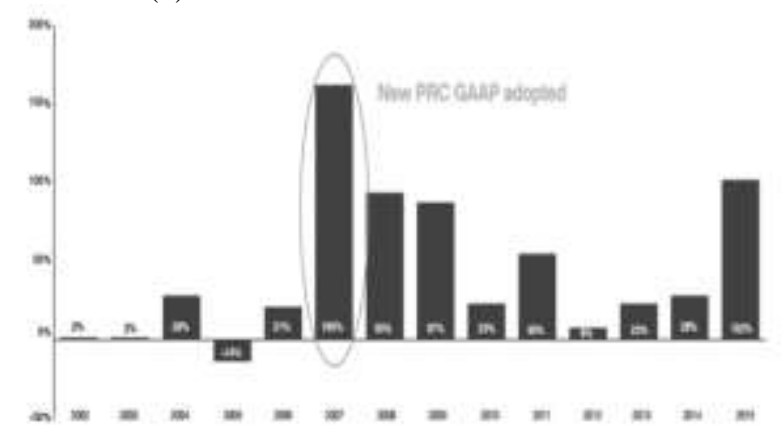

Figure 3 The growth rate of intangible assets on an annualized basis [3]
The tendency to increase capitalization due to the inclusion of intangible property in the asset structure is characteristic of both Russia and the world.

If we consider the structure of the distribution of intangible assets by federal districts, then we can talk about the strong concentration of this indicator in the Central Federal District (Fig. 4), in particular in Moscow.

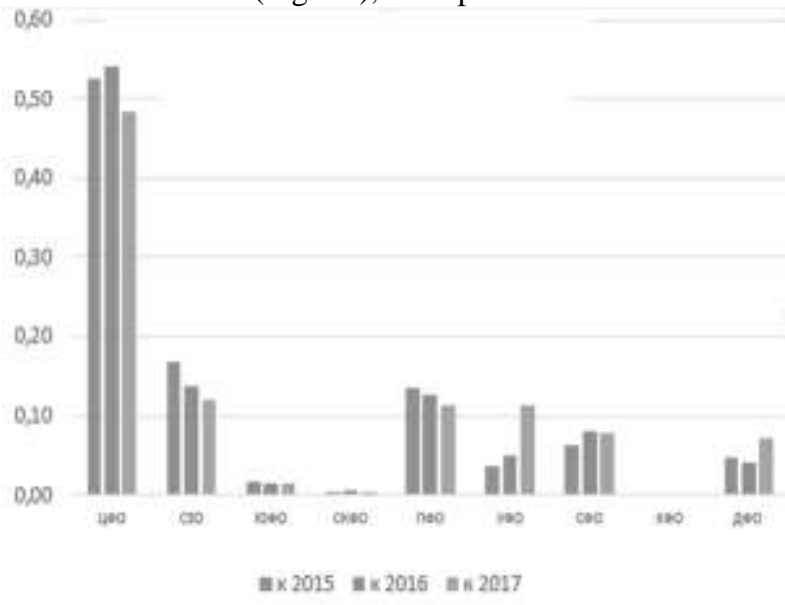

Figure 4 The share of intangible assets by federal districts [4]

\section{RESEARCH RESULTS}

More than $90 \%$ of intangible assets in the country are concentrated in the Central Federal District, and during the period of crisis in the economy, an increase in the concentration of intangible assets is also observed (20072009). The concentration of intangible assets in the Central Federal District can be explained by the concentration of enterprises in this district, a rich scientific base, the presence in the central district of the head offices of large firms, etc. Thus, multinational companies, as a rule, transferring production to other countries, leave technology development and marketing in the central office promotion of goods - that is, intangible property, which is reflected in the balance sheets as intangible assets.

If we consider the distribution of intangible assets in other federal districts, then from Figure 5 it can be seen that in 2007 the maximum variation in distribution was observed for intangible assets, the Volga Federal District was the leader. With an increase in the concentration of intangible assets in the crisis period, the spread in the values of intangible assets in the districts becomes insignificant. These figures confirm two hypotheses:

A high concentration of intangible assets is characteristic, because the intellectual component of the company and its intangible property is deployed in the head office. The high concentration of intangible assets by region reflects the location of research centres;

In a crisis, there is an increase in the concentration and share of intangible assets, because firms aim to increase 
assets. Intangible property acts as a tool for the capitalization of company assets.

Thus, we can conclude that intangible property also performs some representative function, i.e. makes the company more attractive in the eyes of investors. According to Brand Finance, the most intangible nations are: French, Italians, Belgians, Germans and Portuguese. The Russians are included in the ranking, but are at the end of the list, adjacent to the Indians, Peruvians and Cypriots. [8] This fact, in our opinion, is explained by accounting features, trends towards the specification of intangible property within the country (for example, obtaining patents). At the same time, according to Brand Finance, the most intangible industries in the world became in 2016: advertising, pharmaceuticals, cosmetics, products, media, drinks, software and the Internet.

\section{DISCUSSION OF RESULTS}

We have analysed the balances of companies that are in the top of the best global brands according to the Best Global Brand version. We analysed the share of intangible assets, the share of reputation and the total share of the intangible component (intangible assets and reputation in the total volume of assets). We selected the companies included in this rating for analysis, assuming that their assets and reputation would be higher than average. We also analysed the companies that own Russian brands included in the Best Global Brand top.

When analysing companies that own global brands, it was found that the five leaders in the share of intangible assets in the structure of the company's assets belong to: Gucci, IKEA, Louis Vuitton, Budweiser. The share of intangible assets in Gucci reaches $47 \%$ of total assets, the brand takes 41 place in the ranking of Best Global Brand. [5-7] The list of leaders in terms of the volume of intangible assets mainly included companies producing luxury goods (Gucci, Louis Vuitton) and companies producing consumer goods (Pampers, IKEA, Budweiser, Pepsi) (Fig. 6). Such companies need a recognizable brand to promote their product. Brand value is reflected in the structure of intangible assets. When buying luxury goods, the consumer usually pays for the purchase of intangible property of the company to a greater extent: technology, a symbol of success, involvement in the history of the company, emotions, etc. For example, a car that has left the salon immediately loses value because it can no longer be sold in the salon and the buyer does not receive the proper emotions and service when buying.

We also analysed the rating of companies that had the highest share of reputation in the structure of assets. SAP, a software developer, became the leader; the share of reputation in the asset structure was $54 \%$. However, the large volume of reputation on the balance sheet of the company is often due to mergers and acquisitions taking place with the company. The difference between the book value and the market value is taken into account on the balance sheet as the company's reputation, since SAP participated in a number of mergers and acquisitions. SAP is also included in the Forbs rating of the largest companies in terms of assets. [10] According to the share of reputation in the structure of assets, they were among the leaders: SAP, Budweiser, Accenture, Pampers, Gillette, Facebook (Fig. 6) Thus, the leading companies are producers of consumer goods, companies engaged in information technology and consulting services.

Our goal is to determine the share of intangible property, which is reflected in the structure of company assets, to identify and analyse the most intangible companies. To do this, we combined the volume of reputation and intangible assets and calculated their total share in the assets of the company (Fig. 5)

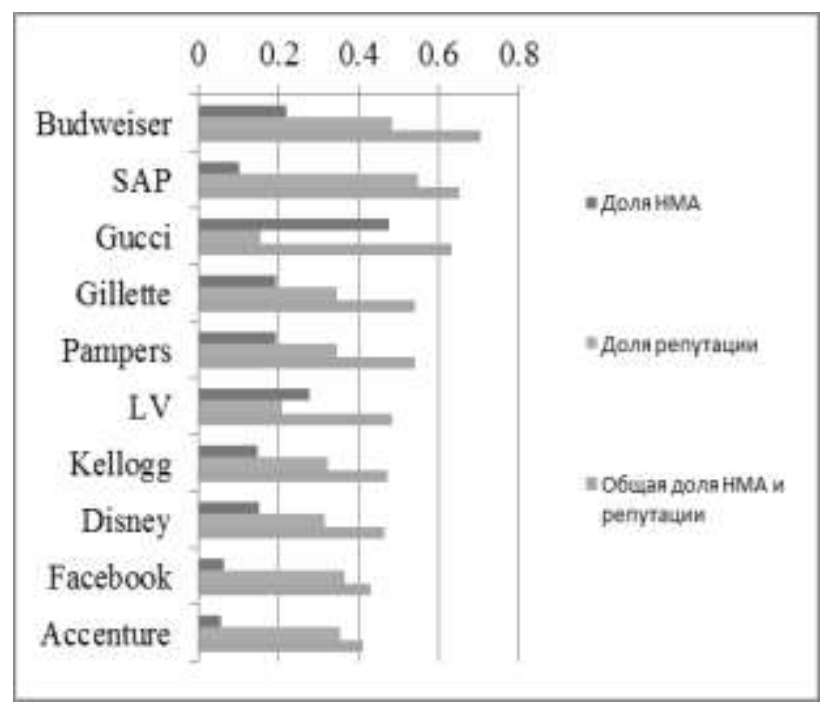

Figure 5 The general level of intangible assets of companies [11]

According to the results of the analysis, it is evident that the most "intangible" companies among companies with a high brand value are manufacturers of consumer goods, and all of these companies have a large part of their assets. At Budweiser, the share of intangible assets and reputation accounts for more than $70 \%$ of all assets (Fig. 5).

Also, in this rating there are companies - manufacturers of luxury goods, their brand and its value in the structure of assets (Gucci, Louis Vuitton) and companies working in the field of information technologies (SAP, Facebook) prevail. It was suggested that companies with marketing intangible property also have other types of intangible property and tend to commercialize and record it $[12,13]$. This assumption was justified, since the total share of intangible assets and reputation in the structure of assets of foreign companies reached $70.4 \%$ (Budweiser), a similar indicator in Russian companies reached $86.6 \%$ (Mail.ru).

We also analyzed the balances of Russian companies that entered the top Best Global Brand 2014. In terms of the share of intangible assets in the structure of assets, the leaders were Baltika (74\%) and Tonus $(41 \%)$ (table 1). Basically, the rating is presented by companies producing mass consumption, banks, companies engaged in information technology. A distinctive feature for Russian 
intangible component in the petrochemical complex is explained by patenting work. In the case of banks and transport companies, these are investments in brand formation.

Thus, we have determined the level of intangibility and the inclusion of intangible property of companies in their financial statements. The industries that are characteristic of the foreign market and the Russian market, where there is a large commercialization of intangible property, are distinguished. The structure of the intangible component of these companies is studied.

Discrepancies were revealed in the Brand Finance rating and our rating of the company's intangibility level. Brand Finance refers to advertising, pharmaceuticals, and cosmetics as the most intangible industries. According to our data, they are not among the top ten; the share of their intangible assets in the asset structure was about $30 \%$. In general, these industries are leaders in the volume of international patent applications and trademark applications, and not in the value of intangible assets (For example, the French company L'Oréal filed 130 product applications in 2016 [14,15].

We studied the dynamics and development trends of intangible assets in Russia and in foreign countries, analyzed the concentration of intangible assets in federal districts, and concluded that in a crisis there is an increase in the concentration and share of intangible assets, because firms aim to increase assets. Intangible property acts as a tool for the capitalization of company assets. According to the results of the analysis, we can say that the distribution of intangible property in Russia is uneven, which is explained by the uneven distribution of research centers, the concentration of enterprises and their organizational policies.

\section{ACKNOWLEDGMENT}

The study was supported by the Grants Council of the President of the Russian Federation, project No. MK-2702.2019.6

\section{REFERENCES}

[1] Compiled by the author based on Rosstat data. URL: https://www.fedstat.ru/indicator/37175 (accessed date: $01 / 28 / 2019$ )

[2] Compiled by the author based on data from Rosstat. URL: https://www.fedstat.ru/indicator/37175 (accessed date: $01 / 28 / 2019$ )

[3] Brand Finance. Access Mode: Acrobat Reader. URL:

http://brandfinance.com/images/upload/gift_report_201

6_for_print.pdf(address: February 9, 2007) 
[15] Martins, M.M., Morais, A.I., Isidro, H., Laureano, R. Intellectual Capital Disclosure: the Portuguese Case. Journal of the Knowledge Economy, 2018, 9 (4), p. 1224-1245 DOI: https://doi.org/10.1007/s13132-016$0412-6$

Demographic Determinants of Household Expenditures in OECD Countries, in Procedia Economics and Finance. 2015. DOI: https://doi.org/10.1016/S22125671(15)00686-3

[6] Larionova N.; Varlamova J. Correlation Analysis of Macroeconomic and Banking System Indicators, in Procedia Economics and Finance. 2014. (DOI: 10.1016/S2212-5671(14)00724-2)

[6] Compiled by the author based on data from Rosstat. URL: https://www.fedstat.ru/indicator/37175 (accessed date: $01 / 28 / 2019$ )

[7] Brand Finance. Access Mode: Acrobat Reader. URL:

http://brandfinance.com/images/upload/gift_report_201 6_for_print.pdf (accessed: 02/09/2019)

[8] Calculated by the author based on Gucci Group materials.URL:http://www.finanz.ru/balans/Gucci_Gro up_1 (date of access 03.03.2020)

[9] The World's Biggest Public Companies. Forbs. URL: https://www.forbes.com/global2000/\#/page:18 (accessed: 03/18/2020)

[10] Compiled by the author on the basis of the analysis of company balance sheets for 2016 .

[11] Yrieva O.V., Butov G.N., Yrieva O.Y., Fakhrutdinova A.V. Formation and Development of An Administrative Staff Reserve in Tatarstan, in Procedia Social and Behavioral Sciences. - 2015. - Vol. 191. - P. 1135 - 1138. DOI: 10.1016/j.sbspro.2015.04.458.

[12] Fierro, A., Aranburu, I. Airbnb branding: Heritage as a branding element in the sharing economy.

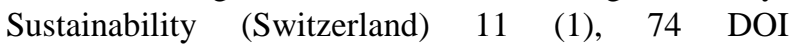
https://doi.org/10.3390/su11010074

[13] The World's Biggest Public Companies. Forbs. URL: https://www.forbes.com/global2000/\#/page:18 (accessed date: 03/18/2019)

[14] The USA remains the leader in the number of international applications for patents and trademarks / WIPO World Intellectual Property Organization URL: http://www.wipo.int/pressroom/ru/articles/2016/article_ 0002.html (accessed: 18.03. 2020) 